Agro Ekonomi Vol. 28/No. 2, Desember 2017

\title{
FACTORS AFFECTING ONLINE PURCHASING OF LOCAL FOOD
}

\section{Faktor-Faktor Yang Mempengaruhi Pembelian Makanan Khas Daerah Secara Online}

\author{
${ }^{1}$ Avivah Rahmaningtyas, ${ }^{2}$ Slamet Hartono, ${ }^{2}$ Any Suryantini \\ ${ }^{1}$ IAAS INDONESIA LC Universitas Brawijaya \\ ${ }^{2}$ Faculty of Agriculture, Universitas Gadjah Mada
}

St. Flora, Bulaksumur, Caturtunggal, Depok District, Sleman Regency

avivahrahmaningtyas@gmail.com

Diterima tanggal : 20 Juni 2017 ; Disetujui tanggal : 18 September 2017

\begin{abstract}
The purpose of this research are to analyze which factors can influence Indonesia's consumer intention to buy local food by online and whether the intention can affect to purchasing decision or not. This research used Partial Least Square (PLS) as data analysis with significance level 5\%. There are several requirements to fulfil the criteria of data anlaysis, they are convergent validity, discriminant validity, and composite reliability. The result is all of three requirement is achieved. Bootstrapping analysis was used to examine the significance and verify the hypotheses. There were five independent variables and two dependent variables. The independent variables were perceived usefulness, perceived ease of use, perceived trust, perceived risk, and perceived price. The dependent variables were intention to buy and purchasing decision. There are two variables which are significance towards intention to buy, they are perceived risk and perceived price. Perceived risk is significance and consistent with the theory which has negative effect towards intention to buy, while perceived price is significance and has positive effect towards intention to buy. Perceived usefulness, perceived ease of use, and perceived trust are not significant toward intention to buy. Variables intention to buy is intervention variable which affect significantly towards purchasing decision. R-square score for intention to buy is $30.5 \%$ while r-square score for purchasing decision is $25.9 \%$.
\end{abstract}

Keywords : intention to buy, online purchasing, Partial Least Square, purchasing decision

\section{INTISARI}

Tujuan penelitian ini adalah menganalisis faktor-faktor yang dapat mempengaruhi niat konsumen Indonesia untuk membeli makanan khas daerah secara online dan menganalisis apakah niat pembelian akan berpengaruh pada keputusan pembelian atau tidak. Responden yang terpilih yaitu yang pernah melakukan pembelian makanan khas daerah secara online minimal satu kali. Jumlah responden yang disarankan pada penelitian ini adalah minimal 140 orang. Penelitian ini menggunakan Partial Least Square (PLS) sebagai analisis data dengan tingkat signifikansi 5\%. Terdapat beberapa ketentuan untuk memenuhi kriteria analisis data antara lain convergent validity, discriminant validity, dan composite reliability. Hasil pengujian adalah penelitian ini mampu memenuhi ketiga kriteria tersebut. Analisis bootstrapping digunakan untuk menguji signifikansi dan memverifikasi hipotesis. Terdapat lima variabel bebas dan dua variabel terikat pada penelitian ini. Variabel bebas penelitian ini adalah persepsi kemanfaatan, persepsi kemudahan, persepsi kepercayaan, persepsi risiko, dan persepsi harga. Variabel terikat antara lain niat dan keputusan pembelian. Terdapat 
dua variabel bebas yang berpengaruh signifikan terhadap niat beli yaitu persepsi risiko dan persepsi harga. Persepsi risiko dan persepsi harga berpengaruh signifikan terhadap niat beli, sementara persepsi kemanfaatan, persepsi kemudahan, dan persepsi kepercayaan tidak signifikan terhadap niat pembelian. Variabel niat pembelian merupakan variabel intervensi dan berpengaruh secara signifikan terhadap keputusan pembelian. Nilai r-square untuk niat pembelian adalah 30,5\%, sementara nilai $r$-square untuk keputusan pembelian adalah $25,9 \%$.

Kata kunci : keputusan pembelian, niat beli, Partial Least Square, pembelian online

\section{INTRODUCTION}

Internet is one of the invention of technology that is currently widely used by the world community. There are various types of businesses use the internet to support their activity such as textiles, ticketing and lodging, processed products such as food and cosmetics, and many more. E-commerce help consumers to buy goods or services easily, while for company, it can reduce operational and marketing costs.

The data from Badan Pusat Statistik (BPS) after processed by Pusat Data dan Informasi Statistik (Pusdatin) related contribution for Gross Domestic Product (GDP) of agricultural processing industry in 2010 until 2014 show that the food and beverages industry have the most percentage of other industries. The percentage number of GDP for agricultural food and beverage industries is $5.05 \%$ which is the total percentage number for food and beverage is $5.25 \%$. This number show that there is a good opportunity to develop the food and beverage industry in Indonesia through online media.
The weakness of agricultural food and beverages can decrease the consumer's intention to buy the product by online because they consider the product has a high risk. This is evidenced through data from Riset MarkPlus, 2013 (cited in Sudjono, 2015) where the agricultural products do not include in one of "Top ten as the most purchased by online". The research by Canavan and Henchion (2007) explained the reason why consumers not interest to purchase an online food is because the characteristic of product and constraints during delivery, and lack of direct interaction with seller to ensure the quality of product.

Zhou (2017) made a statement that food sell by online should have a unique feature which make different to other food sold in store, so that the consumers will be interested to purchase. A local food has special features and popular in some region (Ivanova, 2014). The features could be different among products. There is product which has a special characteristic of its raw material. There is also product which has a unique shape to make a difference from others. There are currently so many food 
producers who brand their product as local food to attract the attention of consumers. A local food does not have a clear definition, so the producers can introduce the product as local food as long as the food has a special features (Ivanova, 2014; Tomescu, 2015). Nowadays, the competition between the local food producers is so intense because of its attraction to make consumers purchase their products.

The high level of public consumption and the development of internet technology in Indonesia is a good opportunity for local food industry entrepreneurs to develop markets in online media. The character of Indonesian consumers who tend to avoid the risk become the obstacle for local food producers to sell it by online, not forget to mention that agricultural products have a weakness, it can explain the reason why food products do not include in top ten of the most food product purchased by online in Indonesia.

There are factors who affect the consumers' intention and decision to buy local food by online other than perceived risk. They are perceived usefulness, perceived ease of use, perceived trust, perceived risk, and perceived price. These factors have indicators that can explain their effect on purchasing intention and decision. This research is important to do to help local food producers to understand factors which affect consumers' intention and decision purchasing by online, so the producers can make a better selling strategy to attract more consumers.

\section{Perceived Usefulness}

Perceived usefulness describe the value and efficacy of new technology for consumers (Lim, Osman, Salahuddin, Romle, and Abdullah, 2012). Al-maghrabi, Dennis, and Halliday (2011) said that if the value of products from new technology could be achieved, it will lead someone to have positive behaviour. Internet is a new technology in food purchasing, it means that the theory could be applied.

$H 1$. Perceived usefulness has a positive effect towards intention to buy

\section{Perceived Ease of Use}

Someone who had experience toward technology system need less effort to operate, this is the indicator of perceived ease of use (Yeo, Goh, and Rezaei, 2016). Chiu et al. (2014) said that the easier to use internet will affect consumers to make purchasing.

H2. Perceived ease of use has a positive effect towards intention to buy

\section{Perceived Trust}

Uzun and Poturak (2014) said that trust related with security or guarantee. A detail information about product will be one of the factors who can increase consumers' trust and feel safe to make transaction. The convenience to access 
the website, the accuracy of information, contact company, and provide many information from other resources are an important factors to affect consumers' decision to buy online product. The company should analyze the things what makes consumers worry and decrease their trust to buy the products.

H3. Perceived trust has a positive effect towards intention to buy

\section{Perceived Risk}

Consumer tend to evaluate product which sell by online has a high risk. This is due to consumer can not see the physical state of the product directly, they should give a personal contact as delivery procedures, and there is no interaction with seller so it can decrease their trust to buy (Javadi, 2012; Uzun dan Poturak, 2014). The more risk faced by consumers, the less possibility to make purchasing, vice-versa (Javadi et al, 2012).

The company can lowered perceived risk by giving a guarantee such as return warranty or ensure the confidentiality of the consumer's personal data (Liu, Brock, Shi, Chu, and Tseng, 2013). It can affect consumers' decision to buy their product. Not many online stores do this strategy because they do not know the importance of warranty for consumers.

H4. Perceived risk has a negative effect towards intention to buy

\section{Perceived Price}

Price is one of important factor for consumer to make purchasing decision. Pricing by the company should be tailored to the financial capabilites of consumers. This research use three indicators related to perceived price to measures its influence towards buying intention of online local food, they are affordable price, competitive price, and price according to quality. Consumers tend to consider product's price because they can compare competitior price and choose a cheaper ones by internet easily (Oktaviyanti, 2015). Price strategy which can do by company is show the detail price such as product price, shipping cost, price changes, and taxes. This is due to consumers do not like about price uncertainty (Kaur and Quareshi, 2015).

H5. Perceived price has a positive effect towards intention to buy

\section{Intention to Buy}

Intention to buy is possibility of consumer will make purchasing in the future. Consumer does not make a decision to buy, but sometimes they have an intention to make transaction. The indicators which can be used to analyze how much possibility of consumer make a purchasing are explorative interest, transactional interest, referential interest, and preferential interest (Ferdinand, 2002 cited in Palwa, 2014).

H6. Intention to buy has a positive effect toward purchasing decision 


\section{METHODS}

Primary and secondary data were collected to support this research. Primary data was obtained by sharing the google link to social media and chatting aplication. Secondary data was got from books, journals and internet.

The method of analysis used was SEMPLS with SmartPLS version 2. The total number of samples research were 159 . The sampling technique used was non-probabilty sampling with purposive sampling method. The study population used was individuals who access google form, while research samples were individuals who bought a local food at least one times.

\section{Stages of SEM-PLS Analysis}

\section{Model Conseptualization}

The path diagram was evaluated by looking the value of loading factor its manifest variables with criteria score was $>0.5$. The manifest which had loading factor scores $<0.5$ should be eliminated from path diagram. The path diagram could be seen in Figure 1.

\section{Conversion of Path Diagram to Equation} $\mathrm{Y} 1=\mathrm{aX} 1+\mathrm{bX} 2+\mathrm{cX} 3+\mathrm{dX} 4+\mathrm{eX} 5+$ $\mathrm{z} 1$

$\mathrm{Y} 2=\mathrm{fY} 1+\mathrm{z} 2$

$\mathrm{Y} 3=\mathrm{fY} 2+\mathrm{z} 3$

Description:

Y1 = Intention to Buy (IB)

$\mathrm{Y} 2=$ Purchasing Decision $(\mathrm{PD})$
$\mathrm{X} 1$ = Perceived Usefulness (PU)

$\mathrm{X} 2=$ Perceived Ease of Use (PEU)

$\mathrm{X} 3=$ Perceived Trust (PT)

$\mathrm{X} 4=$ Perceived Risk (PR)

$\mathrm{X} 5=$ Perceived Price $(\mathrm{PP})$

\section{Parameter Estimation}

Ghozali and Latan (2012) explained that the purpose of outer loading significance was for evaluate path coefficient of latent variables from its indicators. The criteria for manifest variable to be called significantly correlate towards their latent variable was measured with t-statistic in outer table should be more than 1.960 (level of significance 5\%).

\section{Outer Evaluation}

Three things that would be evaluated were convergent validity, discriminant validity, and composite reliability. Assesment criteria of convergent validity was that AVE score should be $>0.5$ and the validity was proved. Discriminant validity would be approved if the AVE root value of each construct was more than correlation score between construct. The value of composite reliability would be approved if its score was $>0.7$.

\section{Inner Evaluation}

The evaluation used was the value of R-square for endogenous variable with resampling procedures, which the analysis used was bootstrapping to get stability 


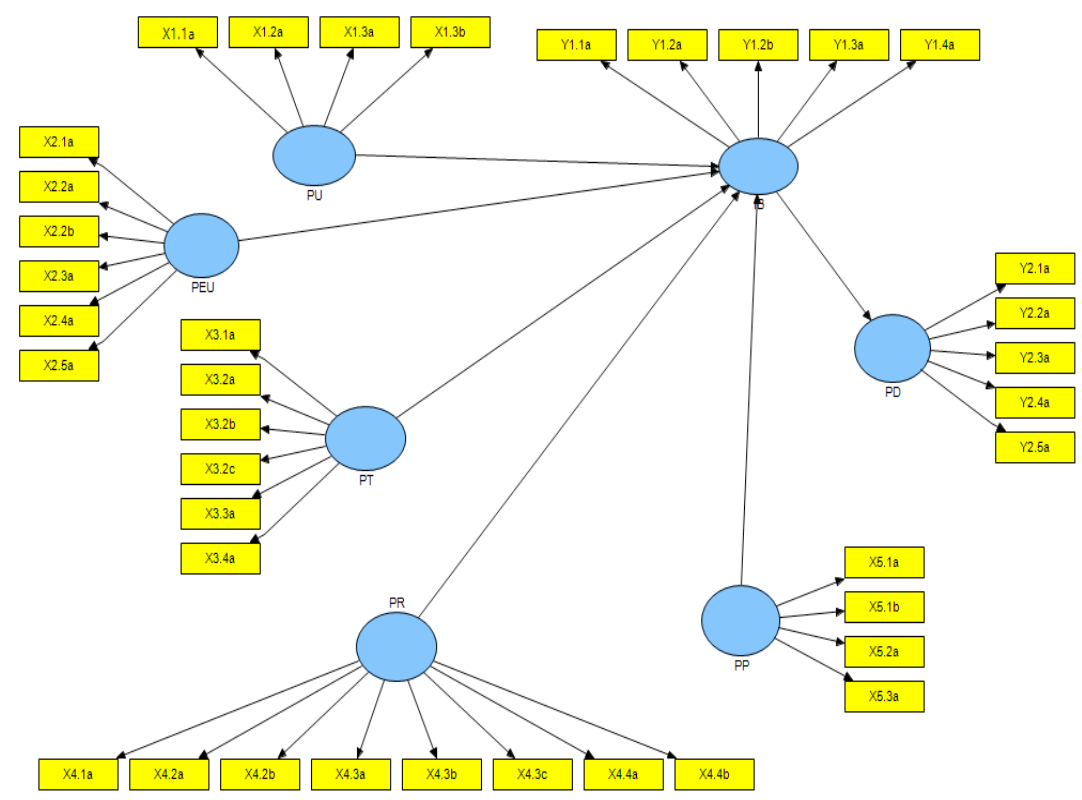

Figure 1. Research Path Diagram

from estimation. The amount of R-square showed the influence of exogenous latent variable toward endogenous latent variable (Ghozali and Latan, 2012). The endogenous variables in this research were Intention to Buy (IB) and Purchasing Decision (PD). Each factors had five different indicators.

\section{Hypothesis Testing}

Significance of hypothesis testing did by compare t-statistic with its t-value. The standard of t-value used for the research was 1.960 , which its value was in the level of significance 5\% (Ghozali and Latan, 2012).

\section{RESULTS AND DISCUSSION}

\section{Path Diagram Construction}

There are manifest variables which have loading factor score $<0.6$, so it should be eliminated from path diagram. They are X1.1a (0.559). X2.a (0.282), X2.2a (0.516), X5.2a (0.582), Y1.1a (0.357), Y1.3a (0.573), Y2.2a (0.570), X2.2b (0.589), and $\mathrm{X} 4.1 \mathrm{a}(0.560)$. The path diagram can be seen in Figure 2.

Manifest Variables Description:

$\mathrm{X} 1.1 \mathrm{a}=$ shopping faster

$\mathrm{X} 1.2 \mathrm{a}=$ compare more products

$\mathrm{X} 1.3 \mathrm{a}=$ get many information

$\mathrm{X} 1.3 \mathrm{~b}=$ get information faster

$\mathrm{X} 2.1 \mathrm{a}=$ buy without much help

$\mathrm{X} 2.2 \mathrm{a}=$ less physical effort

$\mathrm{X} 2.2 \mathrm{~b}=$ less mental effort

$\mathrm{X} 2.3 \mathrm{a}=$ ease of payment system

$\mathrm{X} 2.4 \mathrm{a}=$ get information easily

$\mathrm{X} 2.5 \mathrm{a}=$ find product easily

$\mathrm{X} 3.1 \mathrm{a}=$ halal certificate

$\mathrm{X} 3.2 \mathrm{a}=$ trusted contact information

$\mathrm{X} 3.2 \mathrm{~b}=$ trusted product information 


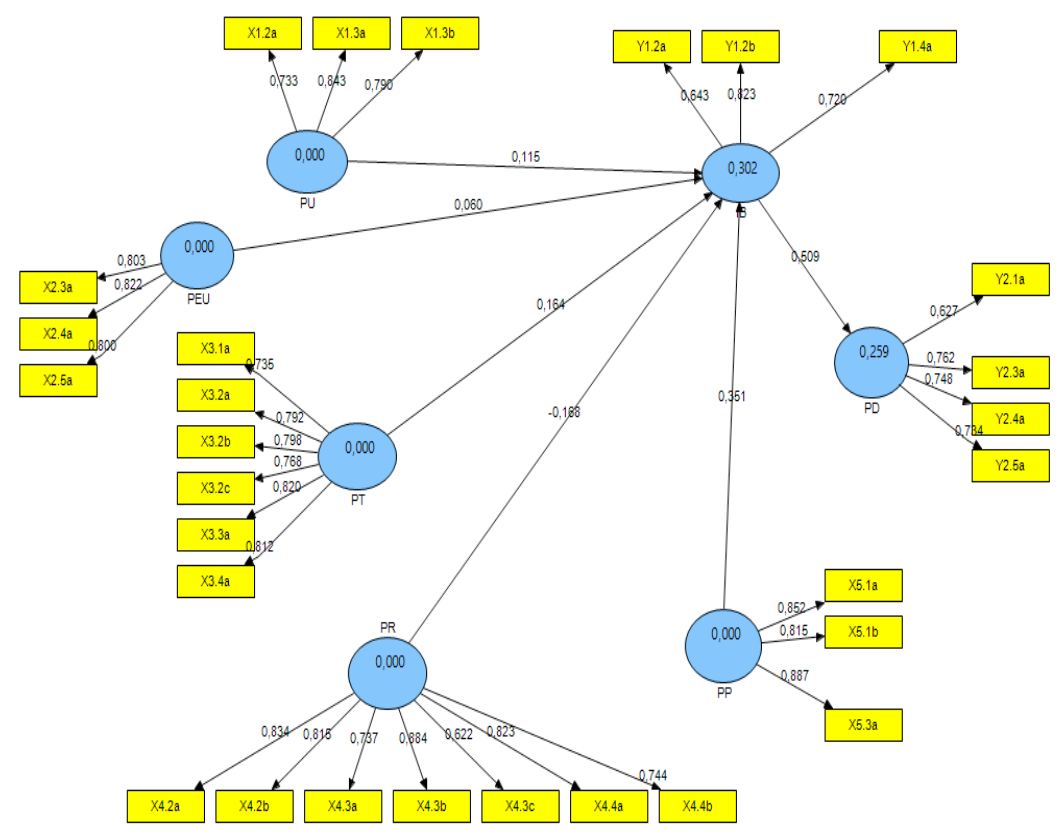

Figure 2. Path Diagram of Research

$\mathrm{X} 3.2 \mathrm{c}=$ trusted product commercial

$\mathrm{X} 3.3 \mathrm{a}=$ security control

$\mathrm{X} 3.4 \mathrm{a}=$ privacy control

$\mathrm{X} 4.1 \mathrm{a}=$ protected personal data

$\mathrm{X} 4.2 \mathrm{a}=$ return warranty

$\mathrm{X} 4.2 \mathrm{~b}=$ trusted online payment

$\mathrm{X} 4.3 \mathrm{a}=$ product $\mathrm{as}$ expected

$\mathrm{X} 4.3 \mathrm{~b}=$ expired date

$\mathrm{X} 4.3 \mathrm{c}=$ quality assessment

$\mathrm{X} 4.4 \mathrm{a}=$ special packaging

$\mathrm{X} 4.4 \mathrm{~b}=$ delivery on time

$\mathrm{X} 5.1 \mathrm{a}=$ cheaper than offline product

$\mathrm{X} 5.1 \mathrm{~b}=$ price affordably X5.2a $=$

cheap price attraction $\mathrm{X} 5.3 \mathrm{a}=$

price according to quality $\mathrm{Y} 1.1 \mathrm{a}=$

explorative interest

$\mathrm{Y} 1.2 \mathrm{a}=$ persuasive interest
$\mathrm{Y} 1.2 \mathrm{~b}=$ positive words

$\mathrm{Y} 1.3 \mathrm{a}=$ preferential interest

$\mathrm{Y} 1.4 \mathrm{a}=$ transactional

$\mathrm{Y} 2.1 \mathrm{a}=$ first choice

$\mathrm{Y} 2.2 \mathrm{a}=$ influence of information

Y2.3a = brand comparison

$\mathrm{Y} 2.4 \mathrm{a}=$ purchase consideration

$\mathrm{Y} 2.5 \mathrm{a}=$ recommend to others

\section{Conversion of Path Diagram to Equation}

Model of Measurement Structural

$$
\begin{aligned}
\mathrm{IB}= & 0.115 \mathrm{PU}+0.060 \mathrm{PEU}+0.164 \mathrm{PT}- \\
& 0.168 \mathrm{PR}+0.351 \mathrm{PP}+\mathrm{e}
\end{aligned}
$$

Latent variable which has the highest score is perceived price (0.351). Ling, Chai, and Piew (2010) said that consumers tend to see the product value not only from the quality or performance but also the acceptable price. 
$\mathrm{PD}=0.509 \mathrm{IB}+\mathrm{e}$

The equation above explain that intention to buy affect consumer decision to buy local food by online.

\section{Model of Measurement Equation}

$P U=0.733 X 1.2 a+0.843 X 1.3 a+0.790 X$ $1.3 \mathrm{~b}+\mathrm{e}$

Manifest variable of $\mathrm{X} 1.3 \mathrm{a}$ which is get many information, has the highest score in the equation of perceived usefulness. The consumers of online media will more active to search information about product before buy it. The competition of price and quality will be considered by consumers to get the best quality with a lower price.

$\mathrm{PEU}=0.803 \times 2.3 \mathrm{a}+0.822 \times 2.4 \mathrm{a}+$ $0.800 \times 2.5 \mathrm{a}+\mathrm{e}$

The highest score of manifest variable above is $\mathrm{X} 2.4 \mathrm{a}(0.822)$ which is the easiness to search information. This is due to the information is very needed when consumer want to buy a product. Consumers will search many information before make a decision. Consumer make use of internet because it provide many information from various brand that has different taste, size, packaging, and price.

$\mathrm{PT}=0.735 \times 3.1 \mathrm{a}+0.792 \times 3.2 \mathrm{a}+$ $0.798 \times 3.2 b+0.768 \times 3.2 c+$ $0.820 \times 3.3 a+0.812 \times 3.4 a+e$

Security control is the manifest variable of $\mathrm{X} 3.3 \mathrm{a}$ which has the highest coefficient score. Currently the consumer consider security in their transaction process, especially related with the requirement to give their personal contact to online stores. The outsiders can use the personal contact for negative purpose, this is why the company should guarantee their security control.

$$
\begin{aligned}
\mathrm{PR}= & 0.834 \times 4.2 \mathrm{a}+0.815 \times 4.2 \mathrm{~b} \\
& +0.737 \mathrm{X} 4.3 \mathrm{a}+0.884 \mathrm{X} 4.3 \mathrm{~b}+0.622 \\
& \text { X4.3c+0.823X4.4a+0.744X4.4b+e }
\end{aligned}
$$

Expired date is a manifest variable of X4.3b (0.884). Food product has a higher risk than other product because food affect to body directly. The company who sell online food rarely publish the expired date in their product, while consumer can not ensure directly whether the expired date is still long or not.

$$
\begin{aligned}
\mathrm{PP}= & 0.852 \times 5.1 \mathrm{a}+0.815 \times 5.1 \mathrm{~b}+ \\
& 0.887 \times 5.3 \mathrm{a}+\mathrm{e}
\end{aligned}
$$

Manifest variable X5.3a is price according to quality which has the highest score (0.887). The cheap price can attract consumer, but the quality still considered. Especially for food product, consumer will doubt the receipt and making process if the food's price is cheap. Currently, there are so many food producer sell local food in online media so it is not difficult for consumer to find quality product with lower price. 
IB $=0.643 \mathrm{Y} 1.2 \mathrm{a}+0.823 \mathrm{Y} 1.2 \mathrm{~b}+$ $0.720 \mathrm{Y} 1.4 \mathrm{a}+\mathrm{e}$

Manifest variable Y2.1b is positive words which has the highest score. Consumer who has intention to buy try to influence family or friends so they also have interest to purchase by telling them a positive words about product. Someone who tell a positive words show that he or she has an intention to buy.

$$
\begin{aligned}
\mathrm{PD}= & 0.627 \mathrm{Y} 2.1 \mathrm{a}+0.762 \mathrm{Y} 2.3 \mathrm{a} \\
& +0.748 Y 2.4 \mathrm{a}+0.734 \mathrm{Y} 2.5 \mathrm{a}+\mathrm{e}
\end{aligned}
$$

Manifest variables $\mathrm{Y} 2.4 \mathrm{a}$ is purchase consideration which has the highest score. The manifest variables of purchase consideration explain that consumers do not much consideration to buy local food by online. Someone who does not make a much consideration to buy tend to purchase the product. It is due to the consumer already convinced of his choice.

\section{Parameter Estimation}

Ghozali and Latan (2012) said that manifest variable which is significance toward other latent variable has t-statistic $>1.960$.

The table above explain that there is no manifest variables which has score lower than t-statistic 1.960. It means all manifest variables can explain their latent variables well. This is due to the elimination process for loading factor score in the section of path diagram construction.
Table 1. Outer Loading Test Result

\begin{tabular}{ccc}
\hline Manifest & Outer & t-statistic \\
\hline $\mathrm{X} 1.2 \mathrm{a}<-\mathrm{PU}$ & 0.732 & 6.452 \\
$\mathrm{X} 1.3 \mathrm{a}<-\mathrm{PU}$ & 0.842 & 9.349 \\
$\mathrm{X} 1.3 \mathrm{~b}<-\mathrm{PU}$ & 0.790 & 9.545 \\
$\mathrm{X} 2.3 \mathrm{a}<-\mathrm{PEU}$ & 0.803 & 12.513 \\
$\mathrm{X} 2.4 \mathrm{a}<-\mathrm{PEU}$ & 0.822 & 12.707 \\
$\mathrm{X} 2.5 \mathrm{a}<-\mathrm{PEU}$ & 0.800 & 9.952 \\
$\mathrm{X} 3.1 \mathrm{a}<-\mathrm{PT}$ & 0.734 & 16.685 \\
$\mathrm{X} 3.2 \mathrm{a}<-\mathrm{PT}$ & 0.792 & 21.667 \\
$\mathrm{X} 3.2 \mathrm{~b}<-\mathrm{PT}$ & 0.798 & 16.198 \\
$\mathrm{X} 3.2 \mathrm{c}<-\mathrm{PT}$ & 0.767 & 17.370 \\
$\mathrm{X} 3.3 \mathrm{a}<-\mathrm{PT}$ & 0.820 & 22.926 \\
$\mathrm{X} 3.4 \mathrm{a}<-\mathrm{PT}$ & 0.812 & 21.211 \\
$\mathrm{X} 4.2 \mathrm{a}<-\mathrm{PR}$ & 0.833 & 5.252 \\
$\mathrm{X} 4.2 \mathrm{~b}<-\mathrm{PR}$ & 0.814 & 5.214 \\
$\mathrm{X} 4.3 \mathrm{a}<-\mathrm{PR}$ & 0.737 & 3.940 \\
$\mathrm{X} 4.3 \mathrm{~b}<-\mathrm{PR}$ & 0.883 & 5.849 \\
$\mathrm{X} 4.3 \mathrm{c}<-\mathrm{PR}$ & 0.622 & 3.471 \\
$\mathrm{X} 4.4 \mathrm{a}<-\mathrm{PR}$ & 0.823 & 5.844 \\
$\mathrm{X} 4.4 \mathrm{~b}<-\mathrm{PR}$ & 0.744 & 5.382 \\
$\mathrm{X} 5.1 \mathrm{a}<-\mathrm{PP}$ & 0.851 & 24.091 \\
$\mathrm{X} 5.1 \mathrm{~b}<-\mathrm{PP}$ & 0.814 & 16.530 \\
$\mathrm{X} 5.3 \mathrm{a}<-\mathrm{PP}$ & 0.886 & 47.754 \\
$\mathrm{Y} 1.2 \mathrm{a}<-\mathrm{IB}$ & 0.642 & 7.030 \\
$\mathrm{Y} 1.2 \mathrm{~b}<-\mathrm{IB}$ & 0.822 & 26.261 \\
$\mathrm{Y} 1.4 \mathrm{a}<-\mathrm{IB}$ & 0.719 & 10.786 \\
$\mathrm{Y} 2.1 \mathrm{a}<-\mathrm{PD}$ & 0.623 & 6.487 \\
$\mathrm{Y} 2.3 \mathrm{a}<-\mathrm{PD}$ & 0.744 & 9.431 \\
$\mathrm{Y} 2.4 \mathrm{a}<-\mathrm{PD}$ & 0.734 & 9.686 \\
$\mathrm{Y} 2.5 \mathrm{a}<-\mathrm{PD}$ & 0.745 & 14.411 \\
\hline & &
\end{tabular}

Source: Primary Data

Table 2. Correlation Between Latent Variables Part One

\begin{tabular}{cccc}
\hline $\begin{array}{c}\text { Latent } \\
\text { Variables }\end{array}$ & PU & PEU & PD \\
\hline PU & 1.00 & & \\
PEU & 0.404 & 1.00 & \\
PD & 0.246 & 0.197 & 1.00 \\
PT & 0.098 & 0.354 & 0.412 \\
IB & 0.210 & 0.251 & 0.509 \\
PP & 0.169 & 0.261 & 0.335 \\
PR & 0.026 & 0.035 & -0.180 \\
\hline
\end{tabular}

Source: Primary Data 
Outer Model Evaluation

Convergent Validity and Discriminant Validity

Table 3. Value of AVE and Root AVE

\begin{tabular}{lrrr}
\cline { 1 - 2 } \multicolumn{1}{c}{ Variables Latent } & AVE & & Root AVE \\
\hline Usefulness & 0.6236 & 0.7897 \\
Ease of Use & 0.6539 & 0.8087 \\
Trust & 0.6211 & 0.7881 \\
Risk & 0.6147 & 0.7841 \\
Price & 0.7250 & 0.8515 \\
Intention to Buy & 0.5360 & 0.7321 \\
Purchase Decision & 0.5180 & 0.7197 \\
\hline
\end{tabular}

Source: Primary Data

Table 4. Correlation Between Latent Variables Part Two

\begin{tabular}{ccccc}
\hline $\begin{array}{c}\text { Latent } \\
\text { Variable }\end{array}$ & PT & IB & PP & PR \\
\hline PU & & & & \\
PEU & & & & \\
PD & & & & \\
PT & 1.00 & & & \\
IB & 0.399 & 1.00 & & \\
PP & 0.525 & 0.474 & 1.00 & \\
PR & -0.10 & -0.182 & -0.007 & 1.00 \\
\hline
\end{tabular}

Source: Primary Data

The table above show that all of AVE score $>0.5$, so the convergent validity meets the criteria. The evaluation for discriminant validity evaluated from the comparison between root AVE with its score of Table 3 and Table 4. Table 3 and Table 4 show the correlation between manifest variable is fewer than root AVE, so the model meets the criteria for discriminant validity. Convergent validity and discriminant validity are used to know whether the questionnaire can measure the variables appropriately or not. Analysis results of validity in this reaserch show that the questionnaire can measures the variables appropriately.

\section{Composite Reliability}

Table 5. Composite Reliability

\begin{tabular}{ll}
\hline \multicolumn{1}{c}{ Latent Variables } & \multicolumn{1}{c}{$\begin{array}{c}\text { Composite } \\
\text { Reliability }\end{array}$} \\
\hline Usefulness & 0.832091 \\
Ease of Use & 0.850063 \\
Trut & 0.907625 \\
Risk & 0.917037 \\
Price & 0.887684 \\
Intention to Buy & 0.774313 \\
Purchase Decision & 0.810480 \\
\hline
\end{tabular}

Source: Primary Data

The analysis of construct reliability in PLS was evaluated from composite reliability score. Ghozali and Latan (2012) explained the criteria to evaluate construct reliability should be more than 0.7. All score on the table above is $>0.7$, so it can be said the model is reliable. After analyzing the validity and reliability, model was evaluated for its R-square. This evaluation describe the relation between dependent and independent variables.

\section{Inner Model Evaluation}

R-square

Table 6. Score of R-square

\begin{tabular}{cc}
\hline Latent Variables & R Square \\
\hline PU & \\
PEU & \\
PD & 0.259115 \\
PT & \\
IB & 0.302151 \\
PP & \\
PR & \\
\hline
\end{tabular}

Source: Primary Data 
The evaluation of structural model in PLS was evaluated from R-square (Ghozali and Latan, 2012). Table 6 show there are two R-square belong to purchase decision and intention to buy. The score of R-square for purchase decision is 0.259 . It means that purchase decision variable can be explained by intention to buy for $25.9 \%$, while the other factor may be explained outside model for $74.1 \%$. The score of R-square for intention to buy is 0.302 . It means that purchase decision variable can be explained by perceived usefulness, perceived ease of use, perceived trust, perceived risk, and perceived price for $30.2 \%$, while the other factor may be explained outside model for $69.8 \%$.

\section{Hypothesis Testing}

Hypothesis analysis in this research use bootstrapping analysis. For level of significance 5\%, t-value is 1.960 (Ghozali and Latan, 2012). The latent variables which have score lower than 1.960 means it does not significant.

Table 7. Inner Model Evaluation Patch Coefficient

\begin{tabular}{lll}
\hline & $\begin{array}{l}\text { Original } \\
\text { Sample }(\mathrm{O})\end{array}$ & $\begin{array}{l}\text { T-Statistics } \\
(\mid \mathrm{O} / \text { STERR } \mid)\end{array}$ \\
\hline PU -> IB & 0.114876 & 1.800785 \\
PEU -> IB & 0.060482 & 0.833926 \\
PT -> IB & 0.164309 & 1.901815 \\
IB -> PD & 0.509033 & 8.915725 \\
PP -> IB & 0.351085 & 4.201542 \\
PR -> IB & -0.168009 & 2.200371 \\
\hline
\end{tabular}

Source: Primary Data
1) Hypothesis for Effect of Perceived Usefulness Towards Intention to Buy (H1)

Table 7 show the score of t-statistic for perceived usefulness (PU) towards intention to buy (IB) is $1.800<1.960$. It means the hypothesis was rejected and explained that perceived usefulness does not significantly positive effect towards intetion to buy. This also happen to others research about Technology Acceptance Model (TAM). The research by Ashraf, Thongpapanl, and Auh (2014) showed the influence of perceived usefulness and intention to buy is not significant for Pakistan consumers. Perceived usefulness has a big impact if someone is in the earlier stage to adopt technology, but it does not has a big impact for someone who has much experience to use the technology (Adams, Nelson, and Todd, 1992; cited in Ashraf, Thongpapanl, dan Auh, 2014). Indonesian consumers already knew to use internet since some years ago. This is the reason why perceived usefulness does not has effect towards intention to buy online local food. People acknowledge the usefulness of internet technology but it does not mean the benefit is related with buying decision of local food.

2) Hypothesis for Effect of Perceived Ease of Use Towards Intention to Buy (H2)

The results of hypothesis testing showed that t-statistic for perceived ease 
of use does not significant because of the score is $0.833<1.960$. The research did by Juniwati (2014) had the same result. The result may different depends on the kind of products. Renny, Guritno, and Siringoringo (2013) said that ease of use can affect online ticket purchasing. People who don't have time to buy ticket will feel easiness towards online ticketing. It can be explained that perceived ease of use is uncertain whether it can motivate someone to have an intention to buy or not. The function of easiness from internet was only did to search information and compare the quality among food local before make purchasing, but it is uncertain if that person will buy by online or in store.

\section{3) Hypothesis for Effect of Perceived}

Trust Towards Intention to Buy (H3)

The variable of perceived trust does not significant towards intention to buy. It is showed the t-statistic of perceived trust $1.901<1.960$. Some research proved that perceived trust is not significant towards intention to buy directly, but need other variable as intervention. Piriyakul et al. (2015) did a research about the effect of perceived trust and intention to make business transaction. The result was perceived trust did not effect directly toward intention but it was significant indirectly. The indirectlty analysis was a reciprocal process between perceived trust and satisfaction variable to effect intention.
The result was perceived trust which is got from satisfaction variable had a significant effect towards intention to buy, vice-versa.

4) Hypothesis for Effect of Perceived Risk Towards Intention to Buy (H4)

The result of hypothesis show t-statistic score is $2.200>1.960$. It means that perceived risk significantly effect toward intention to buy. As the hypothesis before, it means perceived risk has negative effect. Bianchi and Andrews (2012) analyze the consumers in Chile to see the effect of perceived risk and perceived trust toward intention to buy. The result is perceived risk significantly effect to consumers intention to buy online product, though the consumers did a purchase more than one time. The consumers who often buy product in online media still consider its risk before make purchasing (Bianchi and Andrews, 2012). Pappas (2016) said that there are several factors of perceived risk which is usually consumers will consider it before make online purchasing. The factors are price risks, product quality risks, web-vendor quality risks, and web-vendor security risks.

\section{5) Hypothesis for Effect of Perceived}

Price Towards Intention to Buy (H5)

The result of analysis show that perceived price has significant effect towards intention to buy. Yeo, Goh, and Rezaei (2016) also did a research to see the 
effect to perceived price towards intention to buy in online media. The result was the convenience to search information about product make consumer easily find the price product information before make purchasing. Consumers tend to buy th product which has a lower price with better quality (Ollila, 2011; cited in Yeo, Goh, and Rezaei, 2016). Kaur and Quareshi (2015) said that lower price, better quality, and free shipping cost are the factors which affect consumer intention to buy.

6) Hypothesis for Effect of Intention to Buy Towards Purchasing Decision (H6)

Intention to buy has significant effect towards purchasing decision show from t-statistic score $8.915>1.960$. The result explain that someone who has intention to buy has bigger possibility to buy online local food. The company should analyze what factors are the most important to attract consumers intention to buy that will leading to their purchasing due to the uncertainty of online transaction.

\section{CONCLUSION AND SUGGESTION}

The variables which significantly affect intention to buy online local food are perceived risk and perceived price. The perceived risk of Indonesian consumers are still high. The company who sell local food by online should ensure the security for their consumers.
Perceived price is also considered by consumers to make purchasing. The competition between online local food producers make consumers easily find the price information. The consumers usually will choose a cheaper price with better quality.

Intention to buy has a big influence towards purchasing decision. It means that someone who has intention to buy local food product by online will considering to purchase the product. The company should analyze which factors can be affect consumers intention to buy and will lead their behaviour to purchase the product. It will help company to make a good strategy for their selling. This analysis can be done by giving a questionnaire to potential consumers.

\section{REFERENCES}

Al-maghrabi, T., C. Dennis, and S. V. Halliday. 2011. 'Antecedents of Continuance Intentions towards E-shopping: The Case of Saudi Arabia. Journal of Enterprise Information Management. Vol. 24, pp. $85-111$.

Ashraf, A. R., N. (Tek) Thongpapanl, and S. Auh. 2014. 'The Application of the Technology Acceptance Model Under Different Cultural Contexts: The Case of Online Shopping Adoption'. Journal of International Marketing. Vol. 22, pp. 68-93. 
Bianchi, C. and L. Andrews. 2012.

'Risk, Trust, and Consumer Online

Purchasing Behaviour: a Chilean

Perspective'. International Marketing

Review. Vol. 29, pp. 253-276.

Canavan, O. and M. Henchion. 2007. 'The

Use of the Internet as a Marketing

Channel for Irish Speciality Food'.

International Journal of Retail \&

Distribution Management. Vol.

35,pp. 178-195.

Chiu, C.-M., Wang, E.T.G., Fang, Y.-H., Huang, H.-Y., 2014. 'Understanding Customers' Repeat Purchase Intentions in B2C E-Commerce: The Roles of Utilitarian Value, Hedonic Value and Perceived Risk'. Inf. Syst. J. Vol. 24, pp. 85-114.

Ghozali, I., and H. Latan. 2012. Partial Least Square: Konsep, Teknik, dan Aplikasi SmartPLS 2.0. Penerbit Universitas Diponegoro, Semarang.

Hamdani, R., and J. Kuleh. 2013. Pengaruh Produk, Harga, dan Distribusi terhadap Keputusan Pedagang Eceran Membeli Keripik Usus A y a m pada Perusahaan Bintang Bersinar di Samarinda. Skripsi. Universitas Mulawarman, Samarinda.

Ivanova, L., I. Terziyska, dan J. Trifonova. 2014. 'Characteristics of Traditional
Food-The Viewpoint of The Tourism Business'. Service Management. Vol. 14, pp. 123-130.

Javadi, M. H. M., H. R. Dolatabadi, M. Nourbakhsh, A. Poursaeedi, and A. R. Asadollahi. 2012. 'An Analysis of Factors Affecting on Online Shopping Behavior of Consumers'. International Journal of Marketing Studies. Vol. 4, pp. 81-98.

Juniwati. 2014. 'Influence of Perceived Usefulness, Ease of Use, Risk on Attitude and Intention to Shop Online'. European Journal of Business and Management. Vol. 6, pp. $218-228$.

Kaur, G., and T. Q. Quareshi. 2015. 'Factors Obstructing Intentions to Trust and Purchase Products Online'. Asia Pacific Journal of Marketing. Vol. 27, pp. $758-783$.

Li, Xinxin, and Lorin M. Hitt. 2010. Price Effects in Online Product Reviews: An Analytical Model and Empirical Analysis. MIS Quarterly. Vol. 34, pp. $809-831$.

Lim, Y. J., A. Osman, S. N. Salahuddin, A. R. Romle, S. Abdullah. 2016. 'Factors Influencing Online Shopping Behavior: The Mediating Role of Purchase Intention'. Procedia 
Economics and Finance. Vol. 35, pp. $401-410$.

Ling, K. C., L. T. Chai, and T. H. Piew. 2010. 'The Effects of Shopping Orientations, Online Trust and Prior Online Purchase Experience toward Customers' Online Purchase Intention. International Business Research. Vol. 3, pp. 63 - 76.

Liu, M. T., J. L. Brock, G. C. Shi, R. Chu, and T. Tseng. 2013. 'Perceived Benefits, Perceived Risk, and Trust'. Asia Pacific Journal of Marketing and Logistics. Vol. 25, pp. 225 - 248.

Oktaviyanti, Dwi. 2015. 'Analysis of Marketing Mix and Sales Performance of "Industri Hilir Teh Walini" Product'. Agro Ekonomi. Vol. 26, no. 2, pp. 168-178.

Palwa, A. 2014. Pengaruh Green Marketing terhadap Keputusan Pembelian yang Dimediasi Minat Beli (Studi Pada Pelanggan The Body Shop Di Plaza Ambarukmo Yogyakarta). Skripsi. Universitas Negeri Yogyakarta, Yogyakarta.

Pappas, N. 2016. 'Marketing Strategies, Perceived Risks, and Consumer Trust in Online Buying Behaviour'. Journal of Retailing and Consumer Services. Vol. 29, pp. $92-103$.
Piriyakul, M., R. Piriyakul, O. Chuachareon, M. Boonyoung, P. Piriyakul, and I. Piriyakul. 2015. 'Effects of Trust, Satisfaction and Factors Corresponding to TAM on Intention to Reuse Internet Business Transaction'. International Review of Management and Business Research. Vol. 4, pp. $872-890$.

Renny, S. Guritno, and H. Siringoringo. 2013. 'Perceived Usefulness, Ease of Use, and Attitude towards Online Shopping Usefulness towards Online Airlines Ticket Purchase'. Procedia Social and Behavioral Sciences. Vol. 81, pp. $212-216$.

Sudjono, S. 2015. Daftar dan Kriteria Produk yang Bagus Dijual Online. Access from http:// belajarbisnisinternet.com/daftardan-kriteria-produk-yang-bagusdijual-online/.

Tomescu, A. M. 2015. 'Consumer's Awareness of Traditional Food Labeling - A Local Perspective'. Economic Series. Vol. 24, pp. 562572.

Uzun, H., and M. Poturak. 2014. 'Factors Affecting Online Shopping Behavior of Consumers'. European Journal of Social and Human Sciences. Vol. 3, pp. 163-170. 
Yeo, V. C. S., S. K. Goh, and S. Rezaei. 2016. 'Consumer Experiences, Attitude and Behavioral Intention Toward Online Food Delivery (OFD) Services'. Journal of Retailing and Consumer Services. Vol. 35, pp. 150-162.
Zhou, X. Z. S. D. Y. 2017. 'The Impact of Reference Effects on Online Purchase Intention of Agricultural ProductsThe Moderating Role of Consumers' Food Safety Consciousness. Internet Research Vol. 27, pp. 233-255. 